$\mathrm{N}$-(diethylaminoethyl)-2-methoxy-4-amino-5-chlorobenzamide dihydrochloride (Métoclopramide)

\title{
の腸管運動におよぼす効果
}

\author{
岡山大学医学部 第 2 生理学教室 \\ (主任 福原 武教授)
}

福原 武, 中山 沃, 福田博之, 瀜屋俊招

\section{THE EFFECTS OF N-(DIETHYLAMINOETHYL)-2-METHOXY-4-AMINO-5-CHLOROBEN- ZAMIDE DIHYDROCHLORIDE (MÉTOCLOPRAMIDE) UPON THE INTESTINAL MOTILITY}

Takesi Hukuhara, Sosogu Nakayama, Hiroyuki Fukuda and Toshiaki Neya

Department of Physiology, Okayama University Medical School, Okayama

(Director: Prof. T. Hukuhara)

In dogs Métoclopramide administered intravenously or intramuscularly in the amounts ranging from 0.2 to $0.6 \mathrm{mg} / \mathrm{kg}$. had no influence upon the effects of the mucosal intrinsic reflex, vagal stimulation and the intestinointestinal extrinsic reflex.

It may be concluded that the drug, when given in its therapeutic doses, has no paralytic action upon the intramural as well as spinal nervous elements.

福原ら はネズミの摘出小腸片についての実験から， Metclopramide は腸壁内神経要素に対して麻痺的に作用 し，筋自身に対しては一般に運動立進的に作用するが， 筋が特殊な状態，たとえば異常な緊張上昇状態におかれ た場合には，逆に抑制的に作用すると結論した。てれよ りさき福原ら ${ }^{2)}$ は生体内胃腸について, この薬物の作用

\section{実験 方 法}

実験動物としてはイヌを用いた. 生体内胃腸の運動を 研究する場合には, Pentobarbital sodium $(20 \mathrm{mg} / \mathrm{kg})$ の 静注によって麻酔したもの，ときには除脳, 無麻酔のも の,ときには胸髄を I-II 節の中間で切断したものを用い た. なお生体内胃腸および摘出小腸の運動描記法は前論 文息2) そ述べたとおりである.

壁内神経性要素の健否判断の指標としては粘膜内反射 効果および迷走神経刺激効果をえらんだ. 前者を指標と する場合には，まず腸間膜動脈神経をあらかじめ切断し た長さ約 $30 \mathrm{~cm}$ の空腸片に運動描記用の 2 つのバルー ンを挿入し，その中間に粘膜刺激器を装置した。このも のは図 1 亿示すように軸心（電気ギターのG線, 鋼線に
を研究し, 多くの場合運動がえ進し，少数例で運動の抑 制のおてるととを確認した。

ここで問題となるのは，生体内胃腸においてヒトの治 療量 $10 \sim 30 \mathrm{mg}$ で神経性要素の麻疩が招来されるかど うかというととである。乙の度の実験はての疑問を解決 するために行なわれた.

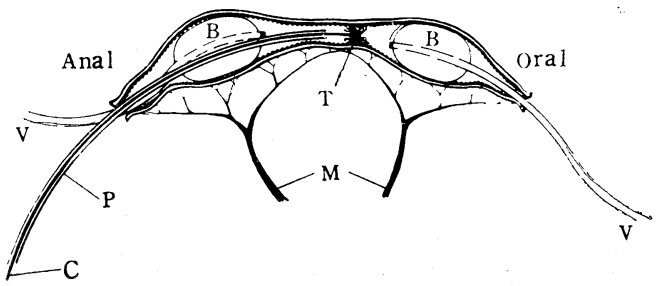

図 1. 小腸粘膜を機械的に刺激するために考案 された刺激器

$\mathrm{B}$ ：バルーン, C : 軸心, $\mathrm{M}$ ：血管神経束, $\mathrm{P}$ ：ポリエチレン管, $\mathrm{T} ：$ ふさ， $\mathrm{V} ：$ ビニ ール管. 
銅線を巻きつけたもの）を polyethylene 管で被覆し， その軸心の先端に木綿糸のふさをつけたものであり, 軸 心を小型モーターで毎秒数回の割合で回転させると, ふ さが粘膜を摩擦刺激するのである. てのさい軸心が鋼板 で螺旋状に巻かれているので回転は軸心にだけに限ら

\section{実}

1. すでに報告3)したように，粘膜の一点を刺激する ならば，腸運動はその口側において著明にたかまり，そ の尾側において抑制される。乙の度の実験では前述の刺 激装置で 8 秒間粘膜を局所的に刺激した。困 $2 \mathrm{~A}$ はその 反応の状態を示す.

つぎに Métoclopramide $0.25-3.5 \mathrm{mg} / \mathrm{kg}$ を静注した後 3〜9分後に前述同様の機械的刺激を加えるに，図 2 B に 示すように常に薬物投与前に少しも劣らない公進効果が 認められた。との結果によって， Métoclopramide のて の程度の量では壁内神経性要素は麻盘されないというと とができよう。

2. 頸部迷走神経の切断末梢端刺激は一般に困 $3 \mathrm{~A}$ に 示すように，著明な小腸運動六進をひきおてす．ついで Métoclopramide の大量 $3.5 \mathrm{mg} / \mathrm{kg}$ 静注後においても前 と同程度の迷走神経刺激によって前とほとんど同様の効 果がひきおてされた（図 3 B)，乙のととは，乙の量では Métoclopramide は壁内に存在する迷走神経の連接部に 何んらの麻痺作用をおよぼさないというととができよ う.

3. 小腸の一部を他部加ら分離し, その内腔を生理的 食塩水で膨らますと, 小腸の他部の運動が抑制されるて
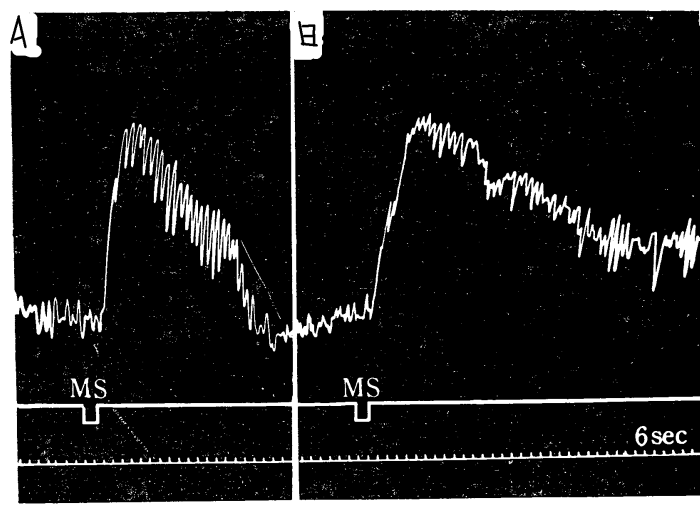

図 2. 粘膜内反射におよほすす MCP の効果

Pentobarbital sodium 麻醉. 上部曲線は十二指腸 運動. シグナル MS は粘膜の局所を8秒間刺激したこと を示す.時標は6秒. A, B はそれぞれ Métoclopramide $1.5 \mathrm{mg} / \mathrm{kg}$ 静注前および 9 分後における刺激部位の 口側における運動六進効果を示す，Bにおいて効果減 弱の認められないことに注意. れ，polyethylene 管がねじれるととがない.

脊髄内腸反射中枢健否の指標としては小腸一小腸反射 あるいは小腸一胃反射を用いた。

使用した薬物, Métoclopramide は藤沢薬品工業から提 供されたものである.

結 果

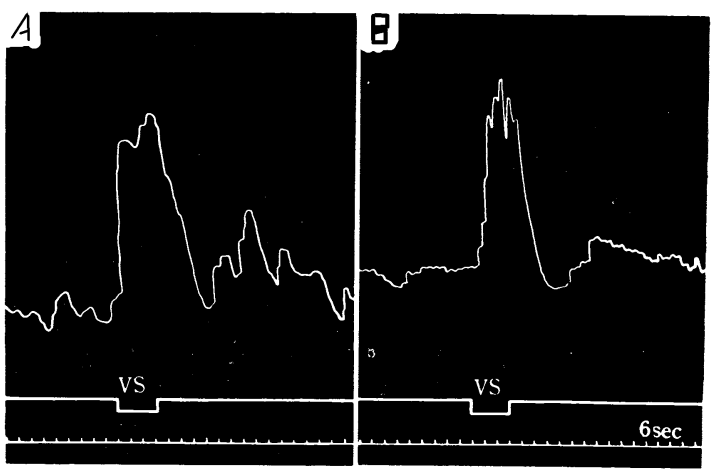

図 3. 迷走神経刺激果効果におよほす MCP の効果 Pentobarbital sodium 麻斩

A : 左頝部迷走神経の切断末梢端を刺激 (VS : 頻数 5/ $\mathrm{sec}$, 持続 $2 \mathrm{msec}, 7 \mathrm{~V}$ の矩形波) すると, 十二指腸運動 が著明に六進する. B : Métoclopramide $3.5 \mathrm{mg} / \mathrm{kg}$ 静 注後 3 分における同様の刺激は静注前とほとんど同様 な結果をひきおこす。

とは周知のととである. この腸一腸抑制反射を指標とし て, Métoclopramide の治療量が春髄内腸反射中枢にど の程度の作用をおよばすかを検討した。

長さ約 $10 \mathrm{~cm}$ の空腸片の内圧を温水注入によって 20 $\mathrm{mmHg}$ にまでたかめると，十二指腸に図 $4 \mathrm{~A}$ に示す ように，顕著な運動抑制がひきおとされる。ついで Métoclopramide $1 \mathrm{mg} / \mathrm{kg}$ を静注した後, 再び同様の圧上昇 を試みるに，図 4 B に示すように，前とはとんど同様な 効果が得られる。乙の結果は腸一腸抑制反射に関係する 脊髄反射中枢が Métoclopramide の治療量によっては麻 痺されないことを示している.

1,2,3 に述べた実験結果によれば, 生体内小腸に関し ては, Métoclopramide の治療量 $(0.5 \mathrm{mg} / \mathrm{kg}$ 以下) で は壁内神経要素ならびに脊髄中枢にはまったく何んらの 麻痺作用もおよばさないといわなければならない。

4. すでに述べたようにネズえの摘出腸管では Métoclopramide が壁内神経要素に麻痺作用をおよばすという 結果が得られている. ての度はさらに生後 1 週の子イヌ の空腸片について同種の実験を行なった。

まず,腸間膜動脈神経刺激 (頻数 $50 / \mathrm{sec}$, 持続 $2 \mathrm{msec}$, $8 \mathrm{~V}$ の矩形波）が著明な運動抑制をひきおてすととを確 かめた後, Métoclopramide (MCP) $10^{-4} \mathrm{~g} / \mathrm{ml}$ を加えた 


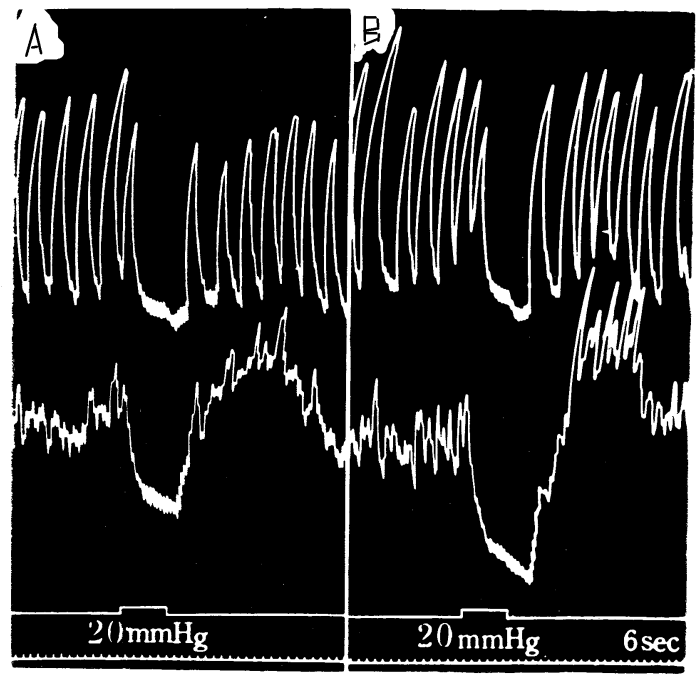

$\mathrm{MCP} 1 \mathrm{mg} / \mathrm{kg}$

図 4. 小腸一胃小腸反射におよぼす MCP の効果 電気ショックの下で脑䯋 I-II の中間で横断. 人工呼吸 施行. 上部曲線は胃, 下部曲線は空腸の運動を 示す. 曲線上に見られる最小の動摇は呼吸によるものである。 $\mathrm{A} ： 10 \mathrm{~cm}$ の空腸の内腔の圧を $20 \mathrm{mmHg}$ にたかめ ることによって，胃および空腸に腸一胃・腸抑制反射 效果が得られる. B :この効果は Métoclopramide $1 \mathrm{mg} / \mathrm{kg}$ 静注後 3 分 30 秒においても減弱せず，小腸で はかえって顕著である.

後 2 分を経て, 前述の神経に前と同様の刺激を適用する に，もはや何んらの効果も得られなかった(図 $5 \mathrm{~A}$ )。な お標本を洗った後には再びはっきり刺激効果が現われ た(図 $5 \mathrm{~B}$ ).

上述の実験は，ネズ之の場合とまったく同様にイヌで も摘出腸では Métoclopramide が神経要素を麻瘴すると

\section{要}

ヒトの治療量 $10-30 \mathrm{mg}$, 体重 $50 \mathrm{~kg}$ として $0.2-0.6$ $\mathrm{mg} / \mathrm{kg}$ に相当する量の Métoclopramide をイヌに静注 するとき，胃腸の壁内神経性要素および脊髄中枢の麻痺 が招来されるかどうかを研究した。

壁内神経性要素の健否の指標としては粘膜内反射効果 および迷走神経刺激効果を, 脊髄反射中枢の健否の指標

$$
\text { 文 }
$$

1) 福原武ら：腸管運動に対する N-(diethylaminoethyl) -2-methoxy-4-amino-5-chlorobenzamide dihydrochloride (Métoclopramide) の 作用機序. 日平滑筋誌，2，22-26，1966.

2) 福原武ら $: \mathrm{N}$-(diethylaminoethyl) -2-methoxy4-amino-5-chlorobenzamide dihydrochloride

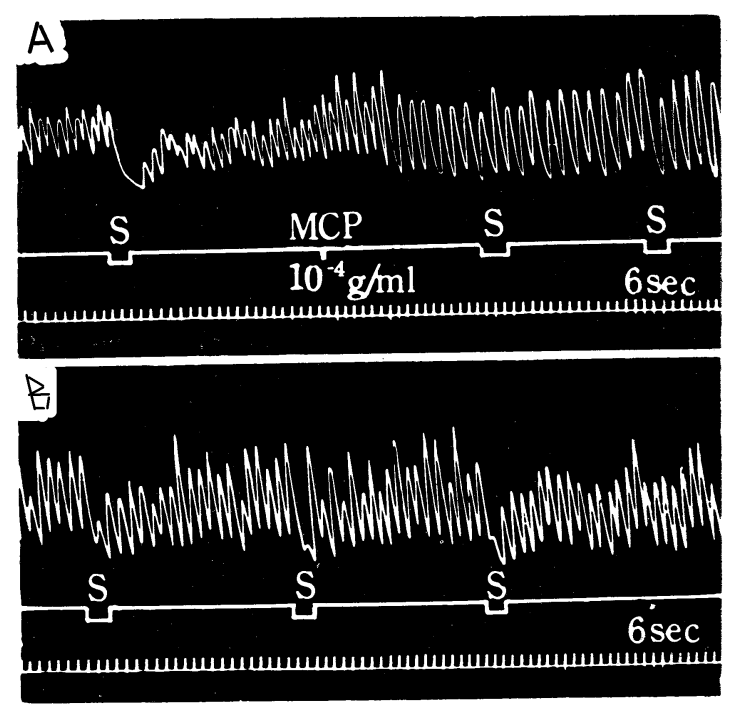

図 5. 摘出空腸片に対する MCP の効果 (イヌ，生後 1 週)

A : 腸間膜動脈神経刺激 S $(50 / \mathrm{sec}, 2 \mathrm{msec}, 8 \mathrm{~V})$ は 著明な抑制を示すことをみた後, Métoclopramide を $10^{-4} \mathrm{~g} / \mathrm{ml}$ の濃度に浴槽中に加えるとその後の神経刺激 はまったく無効となる. B：標本を洗った後では神経 刺激が再び抑制をひきおこす。

とを示している. in vivo と in vitro における実験結果 が異なるのは何故であろうか。ての差異をひきおてすも っとも大切な因子は血液循環の有無ではないであろう か. 血液で養われている場合には，そうでない場合にく らべ，一般に神経要素のこの薬物に対する抵抗力が非常 に大きいのかもしれない.

\section{約}

としては小腸一小腸反射あるいは小腸一胃反射を用い た。

てれら実験の結果によれば, Métoclopramide のヒトの 治療量に相当する量はイヌの壁内神経性要素ならびに脊 髄反射中枢に対して認すへべき麻痺作用をおよぼさないと 結論するととができる。

献

の胃および小腸運動におよぼす効果. 日平滑筋誌, 2, 15-21, 1966.

3) Hukuhara, T., Yamagami, M. \& Nakayama, S. : On the intestinal intrinsic reflexes. Jap. J. Physiol., 8, 9-20, 1958. 